\title{
Sri Lanka: Human Rights in the Context of Civil War
}

\author{
Rudhramoorthy Cheran
}

\section{Abstract}

Violations of human rights in Sri Lanka have been fairly well documented. Unfortunately, the conflict in SriLanka, despite its intensity, has not attracted appropriate international attention. This article is a review of the current human rights situation in Sri Lanka in the context of civil war. The article also ecoaluates the prospects for peace building amidst heightening ethnic tensions, emergency regulations, and the lack of democratic governance in the southern part, a region which is outside the conflict zone.

\section{Précis}

La documentations surles violations des droits humains au Sri Lanka peut être qualifiée de satisfaisante. Malheureusement, le conflit dans ce pays n'a pas attiré l'attention internationale appropriée, en dépit de son intensité. Le présent article passe en revue la présente situation des droits humainsau SriLanka, danslecontexte de la guerre civile. L'article évalue aussi les possibilités de pacification au milieu de tensions ethniques allant en s'intensifiant, les consignes d'urgence, et le manque de gestion démocratique dans la zone sud del'lle, une région extérieure au foyer du conflit.

\section{Introduction}

It has been sixteen years since international journalists have conferred the status of "civil war" on the ethnic "cleavages" within Sri Lanka. The tiny, tear drop-shaped island in the Indian Ocean gained its political independence from the British colonialists fiftyone years ago. However, the post-colonial era has been characterized by long periods of emergency rule, vicious and brutalethnic pogroms, and large-scale human rights violations.

Rudhramoorthy Cheran is a Ph.D. candidate in the Department of Sociology, York University, Toronto.
The current civil war is being waged by the Sinhalese-dominated government and the forces of militant Tamil nationalism spearheaded by the Liberation Tigers of Tamil Eelam(LTTE). Conservative estimates indicate that some 50,000 people have lost their lives as a direct result of the conflict. This figure does not include disappearances. The war has also produced one million internally-displaced people and 700,000 mainly Tamil refugees who have sought asylum in various European countries, North America, Australia and India.

The Sri Lankan civil war is one of the most violent conflicts in the world. Focusing on an aspect of this conflict, the UN Working Group on Enforced and Involuntary Removal of Persons states that Sri Lanka ranks number two in the world in terms of disappearances, next only to Iraq. ${ }^{1}$ Last year, in October, more than 2,500 soldiers and Tigers died in a week-long battle in the northern part of Sri Lanka. Yet, theSri Lankan war is one of the forgotten wars. While international media focuses attention on the self-determination struggles in Kosovo and Kurdistan, Sri Lanka appears to be too far-metaphorically and literallyfrom strategic concerns of the West.

In a recent New York Times editorial onNATO's war against Yugoslavia, the rationing of war news was cited as a familiar problem among American military leaders and their civilian superiors. The editorial went on to note that

military briefings eroded Washington's credibility during the Vietnam war... the Pentagon has continued to try to manage combat information, even during the impressive military successes of the Persian Gulf war. ${ }^{2}$

Theinformation disseminated on the Sri Lankan war is no different. It has been erased from the face of Sri Lankan media by way of government censorship. Nojournalists, foreign or local, are permitted into the war zones. The information that is available is tightly con- trolled, manipulated and delivered through official military press conferences. The whole process is a classic example of what Noam Chomskyidentifies as "manufacturing consent." Even in the absence of censorship, the mainstream media have not been critical of government policy of achieving peace through war.

In 1999, human rights monitors noted that the situation in the conflict areas of Sri Lanka is grave. ${ }^{3}$ There remains, however, a perception that areas that do not directly experience the civil war are safe and that the government respects the human rights of its citizens in those areas. This perception has found its way into the decisions of Canada's Immigration and Refugee Board. One of the most common reasons for rejecting the refugee claims of both Tamils and Tamil Muslims ${ }^{4}$ is the application of the "internal flight alternative" principle-the notion that a person may indeed be at risk of persecution within the northern or eastern regions of the country but is expected to find safety by relocating to the south and the capital city of Colombo. ${ }^{5}$ This is also a perception shared by a number of European governments. ${ }^{6}$

The purpose of this article is to present a dissenting view that casts serious doubts on the validity of these generalizations. The article will also review the human rights situation in Sri Lanka, with particular reference to the developments in the southern part of the country, in order to assess the prospects for human rights compliance and peace building.

\section{Ethnic Enmities}

Let us start by listing certain incidents which have not been reported in any detailby mainstream media in Sri Lanka but only by Sri Lankan human rights monitors and some alternativenewspapers supported by human rights organizations. 
On September 7, 1998, a dispute between two individuals-one Sinhala and the otherMuslim-in Kurunegala, a small town in the south, erupted into a clash between Sinhalese and Muslims in the area. Muslim shops were attacked and burned. Posters in the Sinhala language calling for a boycott of Muslim shops came up in the town. ${ }^{7}$

On September 8, 1998, two Sinhala men were killed on an estate in the Ratnapuara district as a result of a privatedispute. On the nights of September 8 and 9, gangs raided several areas of upcountry Tamils and torched over 300 homes known as line rooms.

On September 26, 1998, in Kochchikade in the Negombo district just outside of Colombo, a disagreement between a Tamil trader and some neighbours over the construction of a parapet wall flared up into a Sinhala-Tamil conflict. Two Tamil shops were burned down and several other incidents of arson and violence were reported.

On February 17, 1999, forty shops belonging to the Muslim community wereburned in Nochiyagama, 206kilometres northeast of Colombo. Tension between Muslim and Sinhalese communities continued for several weeks.

In Kiribathgoda, a suburban town about 15 kilometres from Colombo, a bomb explosion in June 1998 destroyed a newly-built,Muslim-owned communication centre. This was later identified as part of a campaign against Muslim traders in the town. Residents told journalists and members of human rights groups who visited the area that no shop in the Bazaar area was permitted to display a Tamil sign board and that a systematic campaign had been launched to evict the minority traders from the area. Similar developments have been recorded in Welimada, Galagedera, Matale and Puttalam.

The ease with which conflicts that erupt between individuals in the past months have been quickly transformed into ethnic pogroms targeting Tamil and Muslim minorities is significant. The above-mentioned incidents point to a further escalation of ethnic tensions in Sri Lankan society. It is becoming increasingly evident that anti-Tamil or
anti-Muslim riots could well become a part of daily life. In particular, well-orchestrated campaigns against the Muslim traders in certain areas (Galle, Gampaha, Puttalam, Kurunegala) area reflection of a rapidly-deteriorating situation for the minority communities in the southern part of the island.

Careful scrutiny of the above incidents reveals that these are not just isolated events. There is a definite pattern of "ethnic cleansing" that must be placed in a proper context. For the past several years, Sinhala organizationsincluding the National Movement Against Terrorism (NMAT), Sinhala Veera Vidhana (Sinhala Warriors Society), All Ceylon Buddhist Congress (ACBC), Jathika Sanga Sabha (National Assembly of Buddhist Monks), and the Sinhala Commission-have launched a widespread public campaign against the minority communities, while at the same time protesting against political negotiation and third-party mediation to find a peaceful solution to the ethnic conflict. These organizations receive extraordinarily wide publicity in the mainstream Sinhala and English language press. ${ }^{8}$ Some of these organizations also have their own newspapers in the Sinhala language. Some domestic human rights groups-notably Movement forInter racial Justice and Equality (MIRJE), and alternative weekly Sinhalese language newspapers such as Yukthiya and Raavaya-accuse sections of the government as well as the opposition United National Party (UNP) of supporting these movements.

In early November 1998, the Movement against Terrorism (MAT) attempted to disrupt the delegates' meeting organized by the National Peace Council, an umbrella organization of peace groups in Colombo. However, the meeting went on and was attended by some 1,700 people from south and eastSri Lanka. As the meeting was underway, MAT demanded that prominent peace activists be arrested and charged under the Prevention of Terrorism Act (PTA).

Similarly, theSinhala Veera Vidhana (SVV), whose activities gained momentum in 1998, has focused on defending and protecting the interests of the Sinhala Buddhist majority. Under the umbrella of SVV, the United Sinhala Traders Association (USTA), an organization for Sinhala traders, works to promote the interests of Sinhala traders and farmers. Human rights groups allege that USTA was a key player in the attacks against Muslim and Tamil trade establishments. USTA has 614 branches in the Sinhalese-speaking areas. Last year, the USTA began buying paddy from rural Sinhalese farmers, paying reasonably higher prices in competition with traditional Muslim traders. ${ }^{9}$ The rural paddy farmers have been the backbone of the two predominantly Sinhalese political parties that alternated in power in post-independentSri Lanka. The main goal of the SVV project is to mobilize the Sinhalese Buddhists against the perceived threat from the minority Tamils and Muslims. While the government is engaged in a war in the north and east to protect the territorial integrity of Sri Lanka, SVV and its allied organizations have assumed responsibility for guarding south Sri Lanka from the so-called minority threat. In fact, they even fault the government for not waging the war more aggressively.

\section{Democratic Governance: The North-Western Provincial Council Elections}

Sri Lanka has a provincial council system of governance, introduced in 1987 in response to Tamil demands for separation. Elections for the northwestern provincial council were held in January 1999 amidst wide-ranging irregularities and violence. The Center for Monitoring Election Violence (CMEV), an independent non-governmental organization, issued a scathing report after the elections. In the report, CMEV documented systematic voter intimidation, the removal of opposition polling agents through the use of force by government supporters, the blatant stuffing of ballotboxes in full view of election monitors and the media, and the violent presence of the ruling People's Alliance's (PA) in the vicinity of polling booths. The report concluded that the 
validity of the election had been irrevocably undermined. ${ }^{10}$

The CMEV report also accused senior government ministers of contributing to election violations. However, the call by opposition parties, civil rights groups, and CMEV to declare the elections null and void was dismissed by the government. Nonetheless, pressure from various human rights groups as well some representatives of Western governments in Colombo prompted the regime to appoint a commission to inquire into election violations. The serious violation of free and fair elections, which is a basic tenet of democracy, and the government's earlier attempt to postpone provincial elections under emergency ruleimposed throughout the country, point to a progressive erosion of democracy. ${ }^{11}$

\section{Arrests and Detention}

Large-scale, random arrests of Tamils based on their ethnicity continue in many parts of the country. In response to complaints by human rights groups and Tamil political parties that are working with the government, President Chandrika Kumaratunga setup an anti-harassment committee last year. The purpose of the committee was to regularize cordon and search procedures and minimize the suffering and harassment of Tamils in the south. The committee came up with several useful recommendations. The reality on the ground, however, has not changed. The committee proved to be totally ineffective in the face of abductions by undercover police and paramilitary personnel. A case in point was the abduction of a journalist, T. Madhusoothanan by security forces. After two weeks in detention, the journalist was released without being charged.12

Under government-imposed military censorship that began in June 1998, local and foreign journalists are not permitted to enter conflict zones. This has severely limited access to information. It also has enabled the government to evade any public scrutiny of atrocities committed in the war zones. It is within this climate of hostility, censorship, xenophobia, and deteriorating human rights in the south that initiatives for peace and reconciliation need to be examined.

\section{Peace Initiatives}

The broader consensus among various peace groups in Sri Lanka is the call for third-party mediation and the introduction of federalism as a means for achieving an end to the conflict. The various peace groups have formed a coalition called the National Alliance for Peace. The National Peace Council, one of the constituent members of the National Alliance for Peace, held its first conference in Colombo in October 1998. Three thousand people attended it, and the organizers received congratulatory messages from the Sri Lankan government as well as LTTE.

The National Peace Council continued its work of educating Sri Lankan Members of Parliament about peace processes and agreements in other countries. In December 1998, it organized a delegation of parliamentarians from all political parties, local council members, and Buddhist monks to visit Bangladesh, where there is an on-going peace process in the Chittagong Hill Tracts between the Bangladesh government and the Jumma people-based Parabatraya Chattagram JanaSanghati Somity (PCJSS).

The peace groups have achieved some progress when they were able to engage the major business organizations in the struggle for peace. The Ceylon Chamber of Commerce, the National Chamber of Commerce, the Ceylon National Chamber of Industries, the Federation of Chambers of Commerce and Industry in Sri Lanka, and the Exporters Association of Sri Lanka are the organizations thatjointly invited all the political parties and peace groups for a meeting. At the meeting, they came up with a ten-point program for a peaceful settlement of the conflict and called for all political parties to consider their program.

In an attempt toelicit the perspectives of the "border villages" - villages situated along areas in the northeast that separate majority Sinhalese and minority Tamil and Muslim people—on war, several community-based organizations under the auspices of MIRJE have come together as the Co-ordinating Committee for the Border Villages. The committee has initiated a series of factfinding missions to villages located in eight districts: Puttalam, Anuradhapura, Vavuniya, Polonnaruwa, Trincomalee, Batticaloa, Amparai, and Moneragala. The committee's interim report entitled "Emerging issues in the border villages" was submitted to the government and LTTE leadership in December 1998, following a rally which was attended by 5,000 people from the border villages affected by war.

In his November 1998 annual Great Hero's day speech commemorating the fallen LTTE martyrs, the LTTE chief Prabhakaran expressed his willingness to open a dialogue with the government to find a lasting solution to the war. However, the government did not respond to his offer in a positive manner. Yet, in an exclusive interview with the Indian magazine Frontline, President Chandrika Kumaratunga indicated the possibility of negotiations with LTTE, but with a tight time frame. ${ }^{13}$ In January 1999, a South African parliamentary team visited Sri Lanka. South African President Nelson Mandela's offer of mediation has been welcomed by LTTE and peace groups in Colombo. However, theSri Lankangovernment is sceptical about negotiations and it is certainly not willing to accept thirdparty mediation yet. Whatevermaterializes in terms of mediation, there are some fundamental issues that need tobe addressed before embarking upon any peace process.

The prospects for durable peace in the absence of a drastic restructuring of the post-colonial Sri Lankan state, which is highly centralized and unrepresentative of minorities, appear slim indeed.

\section{The Sri Lankan State}

One of themajor factors that has contributed to the ethnic conflict and its escalation into civil war, is the nature and structure of the post-independence Sri Lankan state and its policies toward ethnic minorities. The state apparatus 
itself became monolithic, representing the Sinhala-Buddhist majority in the aftermath of independence. ${ }^{14}$ This process began at the time of independence in 1948. It was replicated by governments of all shapes and stripes, and culminated in the constitutional entrenchment of Sinhala Buddhist dominance over the minorities in the Republican Constitution of 1972 and the 1978 Constitution. The constitutions declared Sinhala the only official language (Article 19) and conferred the "foremost place" to Buddhism (Article9), thereby defining the Sri Lankan polity as essentially a Sinhala Buddhist state. Even in the much-publicized 1995 devolution proposals-later modified to the "legal draft of January 1996" and used as a template to formulate a draft constitution in October 1997-the government failed to address these fundamental issues. The draft constitution proposed to eliminate provisions with regard to the unitary nature of the state, paving the way for change from a centralized, unitary model to a decentralized, federal model. However, the government is clearly reluctant to incorporate multiethnic and multilingual reality of Sri Lankan society into this draft constitution. ${ }^{15}$ The draft constitution has also run into another problem: it has failed to win the support of the main opposition Sinhalese party, the United National Party(UNP). Without support from the UNP, the draft cannot be madeintolaw, as it requires a two-thirds majority approval in Parliament, which the governing coalition does not have. For this reason, there is little likelihood of constitutional reform in the near future.

In my view, the fundamental changes necessary for a peaceful, equal and just coexistence of the different ethnic communities in Sri Lanka should include a restructuring of the state along federal or confederal lines and the transformation of public institutions to be representative and inclusive of the country's population. From the current situation in which the institutions of Buddhist faith and national governance are enmeshed, a policy of secularism must be adopted. For democracy to thrive in Sri Lanka, it is important that primacy is not accorded to any particular religion, language or culture, because unrecognized minority group claims for self-determination, nationhood, and identity are the roots of the current civil war.

\section{Disappearances}

The overalleffect of security legislation enacted at the time of war-Emergency Regulations; Prevention of Terrorism Act (PTA)-and growing impunity have contributed to grave human rights violations. This legislation is still in place. Recommendations made by the UN Working Group on Enforced and Involuntary Removal of Persons and Amnesty International that the legislation be brought in line with international standards, however, have not been implemented. According to Amnesty International reports, more than 600 people disappeared in Jaffna alone in 1996.16 Another 190 cases were reported in 1997. According to the report of the three commissions appointed by the government to inquire into disappearances, 16,742 people disappeared between 1988 and 1994. Another 10,135 cases are still being inquired into. ${ }^{17}$ The human rights groups say that the number of disappearances is more than 60,000 . An analysis in the journal Christian Worker suggests that 60 percent of the people who disappeared were below 30 years of age; 14.82 percent of those disappeared are children below 18 years. ${ }^{18}$ Yet, the present government has not appointed a commission to inquire into disappearances that took place after it came to power in 1994.

There are reasons to believe that the disappearances are not just the result of "excesses," as widely claimed by the successive governments, butare carried out as a deliberate official policy. Indeed, overwhelming evidence indicates that the political leadership has been the cause of the disappearance of tens of thousands of persons. ${ }^{19}$

For example, witness reports and narratives from petitioners to the disappearance commission illustrate the fact that what we are looking at in terms of disappearances in Sri Lanka, is an orchestrated, well-planned state policy which still exists. The U.S. State Depart- ment's country report on Sri Lanka also indicates that the security forces were responsible for 33 extra-judicial killings and at least eleven individuals disappeared in 1998. It also reported that another 25 people disappeared or were killed after being seen last near the army's forward defence lines. ${ }^{20}$ Most disappearances now occurin the context of war, a fact that the government often invokes to justify and explain away the human rights violations.

Amnesty International report (1998) states that torture and ill-treatment in army and police custody are widespread, and the government has unauthorized places of detention in the north, east, and in Colombo. ${ }^{21}$ The U.S. State Department report also states that torture and impunity for those responsible for human rights abuses remain a serious problem in Sri Lanka. ${ }^{22}$

\section{Food as a Weapon of War}

According to Save the Children Fund, 800,000 persons in the war-ravaged north and east now depend on government food rations. Prior to the onset of the civil war, people in these regions were self-sufficient farmers, fisherfolk and employees in the service sector. A government-imposed economic embargo, a ban on fishing, and the continuing insecurity of civil war have decimated the region's economic base and deprived the local population of even minimal level of subsistence. Of the half-million displaced persons in the region, 140,000 people are housed in 350 government-run camps. 457,000 people live in LTTE controlled areas in the districts of Mullaithivu, Vavuniya, Kilinochci and Mannar. ${ }^{23}$

Since 1995, the governmenthas taken control of the distribution of relief supplies on the grounds that such supplies distributed by humanitarian agencies might fall into the hands of LTTE. The Additional District Secretary of Mullaithivu district says that out of 40,000 displaced families that need dry rations in the district, only 14,000 are getting it. 24

Throughout the last quarter of 1998, there were many reports of high rates of malnutrition and starvation among 
more than 80,000 families in Kilinochchi and Mullaithivu districts in the north. These people are suffering due to persistent cuts of dry rations by 32 percent introduced by the government in July 1998. Following protests, the decision with respect to Jaffna and Mannar districts has been reviewed. However, the cuts remained in place in the rest of the northeast.

The issue of food has been a bone of contention between the Ministry of Defence and Tamil government officials in these two districts. While government agents, Doctors without Borders (MSF), the International Committee of the Red Cross (ICRC), and other relieforganizations maintain that many displaced persons in these areas are starving due to denial of food, the government contends that figures of persons eligible for dry rations are inflated and falsified. However, there is no evidence to support the government's claim. In December, the government permitted the Commissioner General of Essential Services to visit some areas under the control of LTTE. After the visit, the Commissioner increased the number of people eligible for dry rations by 50,000 . Still the food supply is inadequate.

The denial of adequate food rations as well as medicine and medical supplies to the areas of conflict are a serious human rights violation. Jordan J. Paust argues that the Sri Lankan government's denial of these necessities to the displaced violates Geneva conventions and constitutes war crimes. ${ }^{25}$

\section{Human Rights Defenders}

There has been a systematic campaign against non-governmental organizations (NGOs) and human rights groups. While the government itself is responsible for the call to monitor NGOs, xenophobic groups and mainstream media are very vocal and active in their campaign against human rights groups. Peace groups are gaining somenew momentum, but they are often slow and too late to respond. Some of the peace groups initially supported the present government. Some senior members of the peacemovementlaterbecame part of the propaganda unit of the government.
This has created the problem of credibility of these groups among the minority communities. The other difficulty associated with the peace lobby is its lack of sufficient grassroots work and support. Nonetheless, in the past few years, peace groups in Sri Lanka have reorganized themselves and appear to be maintaining their independence vis-à-vis the state.

In May 1998, Peace Brigade International (PBI), which had been working in Sri Lanka for nine years providing protection to persons at risk of political violence, terminated its work in Sri Lanka when Defence Ministry officials demanded that PBI submit all its reports before publication.

The government pushed through an amendment to the Voluntary Social Service Organizations (Registration and Supervision) Act, which allowed the government to replace the NGOs' executive committee with an interim board, if there was evidence of fraud or misappropriation. The original act itself allowed government officials to inspect NGO offices and attend meetings. Practically all human rights groups, media monitors, and civil rights groups in Sri Lanka are NGOs. These organizations vehemently opposed the Voluntary Social Service Organizations (Registration and Supervision) Act.

The 1999 Human Rights Watch report also points out that

local and international organizations that worked in the conflict areas or with conflict-affected people faced restrictions on their activities, and some found themselves accused of partisan loyalties.

The report further states that peace groups and groups advocating free expression also ran the risks of censure. ${ }^{26}$

\section{Politics of LTTE}

The emergence of LTTE as a major militant force in the mid-eighties was the result of its unrelenting guerilla attacks on Sri Lankan forces since 1983, and its ruthlessness in eliminating all its opponents, including other Tamil militant groups in Tamil society. In the past twenty years, LTTE has been transformed into one of the most organized, resourceful, and brutal militant organizations in the world.

In Sri Lanka, the president declared that LTTE was an illegal organization and effectively banned it last year. Nevertheless, it is clear that LTTE has been a major player in the struggle of Tamil people. Richard Falk, a respected American political scientist, has suggested that in international law terms, LTTE qualifies as a national liberation movement, much like the African $\mathrm{Na}$ tional Congress (ANC) during the apartheid era in South Africa. ${ }^{27}$ In the context of a systematic human rights violations, LTTE and other Tamil nationalist groups have the right to use force as a means of self-defense and achieving a just and reasonable solution to the problem. However, LTTE must be condemned for exploiting the same tactics of terror meted outby theSri Lankan security forces.

LTTE appears willing and capable of perpetuating a protracted guerilla war as a political strategy until the right "moment," when the international community will accept a separate state for Tamils. In addition to documented authoritarianism and ruthlessness, there is growing evidence of Tamil chauvinism within LTTE and Tamil diaspora communities in Europe and Canada. ${ }^{28}$ The vision of a Tamil nation that is gaining ascendancy is the idea of an exclusive Tamil "nation," devoid of Tamil-speaking Muslims. Muslims were systematically expelled from the Tamil majority northern province by LTTE in 1990. Also, the activities of peace groups in the south are not only viewed with suspicion but are also outrightly ridiculed and condemned by these radical elements. For instance, the respected National Peace Council, an umbrella group based in Colombo, has been labelled by these elements as Sinhala and a racist peace council.

LTTE was responsible for many deaths of civilians in the southern part of the country. The deaths occurred during LTTE suicide-squad bombings in Colombo. At least four political assassinations in the Jaffna peninsula in 1998 were attributed to LTTE. ${ }^{29}$ 


\section{Conclusion}

Peace cannot be imposed from the top. It has to be cultivated from below. This needs an enormous amount of painstaking community mobilization, education and a conducive political climate. It is unfortunate that the political leaders of the parties involved in the conflict are totally incapable of understanding the plight of ordinary people.

The peace process can be a very difficult path toembark upon given the open wounds and the protracted enmity between the communities. However, there is an urgent need for Tamil and Sinhalese nationalists to look very critically at their policies and programs/ pogroms. The strengthening of the peace lobby in the south, whatever limitations it may have, is a necessary and worthwhile project for Tamils.

Any durable peace in Sri Lanka is conditional upon reconciliation among the various communities. In the absence of any meaningful political and social reconciliation, only two scenarios will claim the terrain. One, Sri Lanka will go into the nextmillennium with increased bloodshed and more refugees. Two, if the Sri Lankan state continues with its failure to address the fundamental issues that underlie the conflict, bifurcation of the island will be the logical end result.

\section{Notes}

1. General E/CN.4/1998.

2. The New York Times, 5 April 1999.

3. U.S. Department of State, Sri Lanka Country Report on Human Rights Practices for 1998, February 1999; Human Rights Watch Report, 1998; MIRJE Annual Report for 1998; INFORM, Human Rights Monitor, Colombo, Sri Lanka, situation reports, January-December, 1998.
4. Muslims are also Tamil-speaking but they articulatea distinctive ethnicidentity based on religion and culture in the Sri Lankan political and social context. Thestrengthening of their identity and the subsequent emergence of Muslimidentity politics in Sri Lankan politics are largely the result of Sinhala-Tamil ethnic conflict, in which Muslims were targeted by Sinhalese governments as well as Tamil militants.

5. See, for example, CRDD Decisions U9604802, February 16, 1998; U97-00276, March 25, 1998; and U96-02184, July 16, 1998.

6. For example see Report on Sri Lanka, Ministry of Foreign Affairs, Government of Germany, Bonn, January 1999. The governments of Switzerland, the Netherlands and Norway send rejected Tamil refugees back to Colombo, Sri Lanka.

7. Information relating to all the incidents was from INFORM situation reports, Sarinihar, a fortnightly newspaper in Tamil language, Colombo, and Yukthiya, a Sinhalese language weekly news paper, Colombo.

8. MIRJE, Annual Report for 1998.

9. Sarinihar, issue 165, February 1998;MIRJE, Annual Report for 1998.

10. CMEV report, January 1999, Colombo.

11. Thegovernmentextended emergency regulation to the entire island in August 1998. The regulation remains in place to date and gives the government wide-ranging powers of arrest, detention and disposal of bodies without a judicial inquest.

12. Human Rights Watch Report, 1998; MIRJE, Annual Report for 1998. For unauthorized places of detention, see Amnesty International statement ASA/37/23/1998.

13. Frontline, vol. 15, issue 26 (December 19, 1998-January 1, 1999).

14. For an overview of these developments and roots of the conflict see: A. J. Wilson, The Break-up of Sri Lanka: The Sinhalese-Tamil Conflict (London: C. Hurst \& Co, 1988); Jonathan Spencer, ed., Sri Lanka: History and Roots of Conflict (London: Routledge, 1990).
15. Rohan Edirisinha, "An International Review of Peace Initiatives," Accord, issue 4, August 1998.

16. AmnestyInternational Report, ASA 37/04/ 98, February 1998; ASA 37/24/97, November 1997.

17. The three commissions appointed were for (i) the Western, Southern, and Sabaragamuva Provinces, (ii) the Central, North Central and Uva provinces and (iii) the Northern and Eastern Provinces. The report of the commissions is available at <www.disappearances.org>.

18. Christian Worker, Quarterly of the Christian Workers Fellowship, August, 1998, Colombo, Sri Lanka.

19. See supra note 17 .

20. See supra note 3 .

21. Amnesty International Report, 1998.

22. U.S. Department of State, Sri Lanka Country Report on Human Rights Practices for 1998, February 1999.

23. Save the Children Fund report as cited in Midweek Mirror, Colombo, Sri Lanka, December, 9, 1998.

24. Ibid.

25. Jordan J. Paust, "The Human rights to food, Medicine and Medical Supplies, and Freedom from Arbitrary and Inhuman Detentions in Sri Lanka," in VanderbiltJournal of Transnational Law, vol. 32, 617.

26. The U.S. Human Rights Watch Report, 1998.

27. Proceedings of the case Suresh Manikkavasagar vs. Canada, serially published in Ulagath Thamilar, fortnightly newspaper of the World Tamil Movement, Toronto, Canada 1997.

28. There are several Tamil publications and newspapers that publish extreme Tamil nationalist articles and view points: Ulagath Thamilar, fortnightly, Toronto, Canada; Muzhakkam (Thunder), weekly newspaper, Toronto, Canada; Namnaadu, weekly newspaper, Toronto, Canada; Erimalai, monthly magazine, published in Paris, France.

29. MIRJE, Annual Report for 1998; U.S. Department of State, SriLanka Country Report on Humian Rights Practices for 1998, February, 1999.

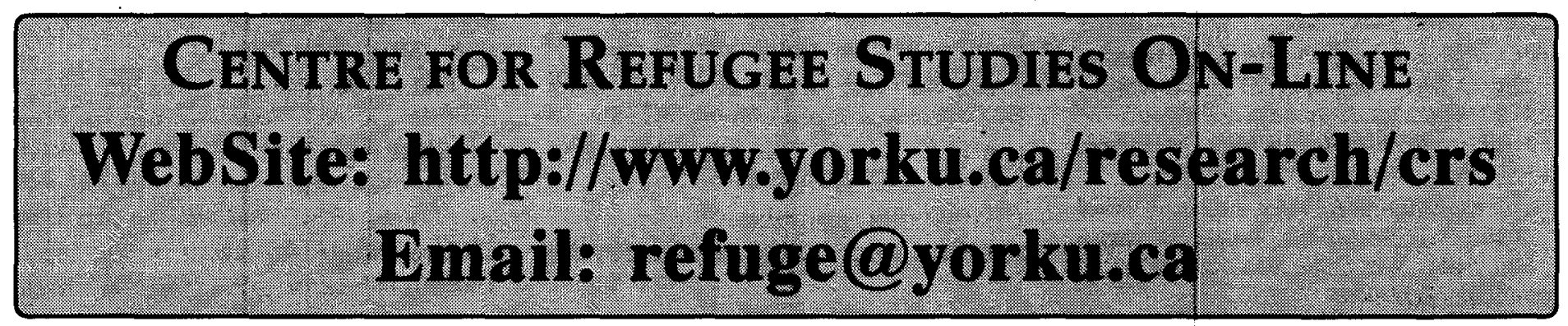

Refuge, Vol. 18, No. 2 (April 1999)

(C) Rudhramoorthy Cheran, 1999. This open-access work is licensed under a Creative Commons Attribution-NonCommercial 4.0 International License, which permits use, reproduction and distribution in any medium for non-commercial purposes, provided the original author(s) are credited and the original publication in Refuge: Canada's Journal on Refugees is cited. 